\title{
Cognitive Neuroscience in Engineering Coursework at Peruvian University Programs
}

\author{
Carlos A. Mugruza-Vassallo and Yolanda C. Mugruza-Vassallo
}

\begin{abstract}
More of the half of the 142 Peruvian universities have undergraduate programs related to Information and Communication Technologies (ICT), bearing in mind the continuous changes in ICT, the present research question was: is there a consistency in coursework supporting new technologies, e.g. Cognitive Neuroscience? Results from 8051 students at electrical ICT programs were: (1) similar number of students in private and public universities; (2) not significant difference between students of private and public universities in the different databases in IEEE at around 39\%, Hinari at around $3 \%$ and ScienceDirect at around 13\%; (3) several different courses related to Cognitive neuroscience were found in different ways at Electronics Engineering programs; and (4) a summer course of Cognitive Neuroscience for undergraduates students was done, with two reaching a masters scholarship. On the other hand, considering Peruvian Computer Science programs, only $22 \%$ of the students have used the IEEE database. Finally, a mixed analysis was done considering coursework and student access to databases. Results pointed to top local universities with low IEEE access and greater IEEE access of other less top universities with coursework related to Cognitive Neuroscience. An example was explained of aboriginal local legend, considering past and current culture at pluricultural place in Peru, where videogames were considered. This contrasted with the low local use of scientific databases and suggested that past and current culture analysis are important as well as solutions or educative adaptations from other countries. All these results suggested that cognitive neuroscience must be part of ICT coursework.
\end{abstract}

Index Terms-Cognitive neuroscience, undergraduate coursework, information and communication technologies (ICT).

\section{INTRODUCTION}

During the development of neuroscience, technology was included, even since Cajal's time. Nowadays, neuroscience is being mixed with ICT technologies. For example, in 2013, a striking fact was the transplant of arms to a veteran American at Johns Hopkins University. He had lost his four limbs in

Manuscript received September 20, 2017; revised November 29, 2017. This work was supported initially by Universidad Nacional de Ingeniería, where part of this manuscript started, next by the Instituto de Investigación Científica de la Universidad de Lima under Grant for "Técnicas para equipos de electrofisiología cognitiva humana y pruebas en paradigmas visual/auditivo" and finally by Universidad Nacional Tecnológica de Lima Surin the process of publication.

Carlos A. Mugruza-Vassallo was with Universidad de Lima, Avenida Javier Prado Este N. ${ }^{\circ} 4600$, Lima, Perú. He is now with the Universidad Nacional Tecnológica de Lima Sur (UNTELS), Av Central Sector 3 Grupo 1A 03, Villa EL Salvador, Lima, Perú (e-mail: cmugruza@yahoo.com).

Yolanda C. Mugruza-Vassallo was with Universidad Nacional de Ingeniería, Av. Tupac Amaru 210, Rímac, Lima, Perú. She is now with the Universidad de Lima, Avenida Javier Prado Este N. ${ }^{\circ} 4600$, Lima, Perú.
Baghdad in 2009. Treatment used an infusion of bone marrow cells from a deceased donor. The preparation, electromyogram and the complexity of the connections of the different tissues have taken 13 hours of surgery and reflect that engineering is taking an important role in surgery of that high complexity [1]. This development is inside the Human Motor Control and was systematically studied based on Maxwell's equations since the 1960s and other recent studies on mathematical methods and how muscle fibers were innervated [2].

Other recent fact in 2014 was the Nobel Prize in Physiology-Medicine won by O'Keefe and Moser couple "for their discoveries of cells that constitute a system positioning in the brain". In 1971, O'Keefe found the first part of this system: a neuron in the hippocampus which was activated each time that the animal was in a particular place, explained by an "internal" map of the cage in the rat brain. At the time, methods were related to the development of small electrode arrays. Later, in 2005, Moser discovered the other part of the "GPS" to identify other types of neurons that allows accurate positioning and layout of itineraries. They developed methods that combined video behavior and imaging made through electrical array measures and spectral analysis [3]. This cognitive spatial map in the brain is a part of the research of Cognitive Neuroscience and ICT analytic procedures and has possible future engineering applications.

While some studies argued about the scientific rigor of education, education is clearly a cognitive science [4]. This has led the interest of the Cognitive Neuroscience to seek a link between new sciences of education and learning. This link has being raised recently in Ecuador not only for classical electronics and programming, but also to seek groups for expand search tasks and capabilities [5]. Moreover, the top ICT institutions in the world [6], such as Massachusetts Institute of Technology (MIT) has an undergraduate course of Computational Cognitive Science in Electrical Engineering and Computer Science department [7] and the Universidade Sao Paulo has 3: Computing, Cybernetics and Cognitive Systems [8] in Computer Science and other two Introduction to Computational Neuroscience [9] and Quantitative Techniques applied to Structural Neuroimaging [10] in Biomedical Informatics.

This study was aimed to see how Cognitive Neuroscience is driven by Engineering undergraduate programs in Peru, to later study how students may reach recent developments and finally to see how were the several naturalistic and sociocritical aspects in different Peruvian regions.

\section{METHODS}




\section{A. Engineering Schools in Analysis}

There are 142 universities in Peru, and then for the detailed needed for the present analysis due to availability of data, Lima region was selected. ICT programs were spread in non-regular consistent geo-graphical distribution across the different regions in Peru. Electronic Engineering is of particular interest because it mixes communication, control and hardware technologies which were important to develop systems to interact with the brain [11]. A poll of questions was realized on 8051 Electronic engineering undergraduate students. The application was filled at Peruvian National Institute of Statistic and Informatics (INEI) using the R + SP WebSer-ver software (module for data processing online) Redatam + SP (Recover Data for small microcomputer Areas, 4th Generation), created by the Latin American and Caribbean Demographic Centre (CELADE) [12]. Therefore, here, the raw data provided by this application was analyzed.

\section{B. Related Coursework in Peruvian Universities}

Courses were taken from the coursework of careers with relevance for cognitive neuroscience in ICT. Therefore individual courses were extracted from current curricula of the universities. Courses, listed for few universities in Lima region, were considered in the following undergraduate programs: Computer Science, Mechatronic Engineering, Electronics Engineering, Informatics Engineering, Industrial Engineering, and Mathematics | Statistics.

\section{Student Access to Peer Review Publications}

The use of undergraduate students in different databases was sought in the raw data of the national census, namely IEEE Xplore, ScienceDirect and Hinari. This raw data was taken from the database at the INEI [12] as described in II-A

\section{Aboriginal ICT Development in Cognitive Science}

An example of development of technologies considering promotion in aboriginal population was analyzed in Iquitos, which belongs to the Amazon region.

\section{E. Cognitive Neuroscience Course in Electrical Engineering Undergraduate Students}

A course was encouraged by the Electrical Department at UNI. This course allowed taking a sample in a summer course of Cognitive Neuroscience. Results here showed 18 months of activity guided by the present authors guided the development of this course.

\section{RESULTS}

\section{A. Engineering Schools in Analysis}

In the curricular coursework, cognitive neuroscience in engineering were considered as part of courses such as Artificial Intelligence, Expert Systems, Computer Vision, Neural Networks and/or some combination of names of such courses or other names like Robotics, Automation or Decision Making. Usually these courses are part of a master or doctorate programs and not always are defined lines of research in cognitive neuroscience. However, they are currently part of the undergraduate curricula of science and engineering careers in several Peruvian universities.
Therefore, in Table I Peruvian universities with Electronics Engineering were shown at each university, the region and the number of students. Twenty five of the 142 universities have Electronics Engineering. There were found 3404 undergraduate students in 11 private universities and 4773 in 15 public universities showing almost the same average student population per university of 309 and 318 students in private and public universities, respectively.

TABLE I: PERUVIAN UNIVERSITIES WITH UNDERGRADUATE STUDENTS IN ELECTRONICS ENGINEERING

\begin{tabular}{|c|c|c|}
\hline Private Universities & Region & $\begin{array}{c}\text { Number } \\
\text { of } \\
\text { Students }\end{array}$ \\
\hline Univ. Católica Santa María-UCSM & Arequipa & 314 \\
\hline Univ. Privada Antenor Orrego-UPAO & Trujillo & 256 \\
\hline Pontificia Univ. Católica Del Perú-PUCP & Lima & 691 \\
\hline Univ. de San Martín de Porres-USMP & Lima & 212 \\
\hline Univ. Ricardo Palma-URP & Lima & 370 \\
\hline Univ. Peruana de Ciencias Aplicadas-UPC & Lima & 272 \\
\hline Univ. Alas Peruanas-UAP & Lima & 335 \\
\hline Univ. Tecnológica del Perú-UTP & Lima & 593 \\
\hline \multirow{2}{*}{$\begin{array}{l}\text { Univ. de Ciencias y Humanidades-UCH } \\
\text { Univ. Andina Néstor Cáceres }\end{array}$} & Lima & 145 \\
\hline & Puno & 137 \\
\hline Univ. de Tacna-UTA & $\begin{array}{l}\text { Tacna } \\
\text { Total }\end{array}$ & $\begin{array}{l}79 \\
3404\end{array}$ \\
\hline \multicolumn{3}{|l|}{ Public Universities } \\
\hline Univ. Nacional de San Agustín-UNSA & Arequipa & 246 \\
\hline \multirow{2}{*}{$\begin{array}{l}\text { Univ. Nacional del Callao-UNAC } \\
\text { Univ. Nacional de San Antonio Abad del }\end{array}$} & Lima & 656 \\
\hline & Cusco & 435 \\
\hline Univ. Nacional de Huancavelica-UNH & Huancavelica & 188 \\
\hline Univ. Nacional San Luis Gonzaga-UNSLG & Ica & 255 \\
\hline Univ. Nacional del Centro del Perú-UNCP & Huancayo & 362 \\
\hline Univ. Nacional Pedro Ruíz Gallo-UNPRG & Lambayeque & 351 \\
\hline \multicolumn{3}{|l|}{ Univ. Nacional Mayor de San } \\
\hline Univ. Nacional de Ingeniería-UNI & Lima & 425 \\
\hline $\begin{array}{l}\text { Univ. Nacional Federico Villarreal-UNFV } \\
\text { Univ. Nacional José Faustino Sánchez }\end{array}$ & Lima & 133 \\
\hline Carrión-UNSACA & Lima & 19 \\
\hline $\begin{array}{l}\text { Univ. Nacional Tecnológica del Cono Sur } \\
\text { de Lima- UNTELS }\end{array}$ & Lima & 281 \\
\hline Univ. Nacional de Piura-UNP & Piura & 526 \\
\hline \multirow[t]{2}{*}{ Univ. Nacional del Altiplano-UNA } & Puno & 368 \\
\hline & Total & 4773 \\
\hline
\end{tabular}

In private universities PUCP $(n=691)$ and UTP $(n=593)$ were the greatest population with $37.7 \%$ of the total, meaning more than $36.4 \%$ (the equivalent of 4 universities). On the other hand, public universities considered in this study consisted on UNMSM $(n=528)$ and UNI $(n=425)$ giving $20.0 \%$ of the overall public population.

\section{B. Related Coursework in Peruvian Universities}

Changes in current coursework at Peruvian universities are expected due to curricular aims introduced by the new Peruvian university law [13], where the revision of the curricula every three years is demanded. In this way, in Table II were listed the names of the courses given in Spanish (Peruvian official language) at universities such as UTP, TELESUP and few are in English (highlighted in italics) at universities such as PUCP, i.e. see courses in italic in Table II: Data Mining and Topic in Advanced Robotics. At UNI exists 
in other careers such as Systems Engineering. Possibly some topics of Cognitive Neuroscience were introduced in other courses depending of the lecturer or the focus of the course. For example, the present author introduced cognitive processing related to adaptive filtering and multiarray processing in courses on Telecommu-nications Eng. and fuzzy control in Electronics Eng. in the UNI (see Table II, on the right). In the UNMSM current undergraduate degrees are in Electronics, Systems, Industrial, and Software Eng. Detailed coursework and different related professional career may be seen in Table II.

Other young universities, such the case of the UCH, the new curricular proposal includes a course of Automation for Self-sustaining Buildings (personal communication). For example, in Scholar Google [14] up to submission date, 229 articles use the term neuroscience of the 2840 articles on the topic of building automation. This may be supported by the curricular change introduced at $\mathrm{UCH}$ in formative research [15].

Bearing in mind, the recent field of neuroscience and the more recently cognitive neuroscience and its link with engineering applications, this link may be seen through: A) The time needed for the brain needs for learning consolidation, B) Undergraduate number of course as a load for learning different aspects of Cognitive Neuroscience.

\section{1) Time needed for learning consolidation}

The time for brain learning is based on computer work and how programming languages are tough using imitation [16]. Also, current results of neurodidactics have started to discuss the learning process for structure and orienting-based programming considers the individual preconditions (e.g. level of previous knowledge and competences), not only considering the time spent for students in the process of learning outside the lectures but also the teacher attitude and synergy with students [17].

\section{2) Undergraduate number of courses as a load for \\ learning different aspects of cognitive neuroscience}

Using the Electronic Engineering perspective described in methods, the courses were found and listed on Table II. These courses are important to study and understand the complexity of the brain, having as a basis after communication, control and hardware technologies. On the other hand, most of the Peruvian universities avoid Electronics due to expensive equipment.

Bearing the previous premises, the better introduction of Cognitive Neuroscience courses in ICT programs the more optimal time spent between lecturers and students and the more courses related. Therefore, coming back to Table II, Mechatronics Engineering at PUCP with 4 courses was found as the better place for developing Cognitive Neuroscience skills. On the other hand, other universities, such as TELESUP with one course would need to work more with time between lecturers and students in order to reach the skills given by the more courses in the other universities.

\section{Student Use of Peer Review Publications}

After processing the basic information of the census were found 4773 Electronic Engineering undergraduate students of public universities in Peru in 2010. Then, 1882 students used IEEE database for coursework, giving $39.43 \%$ of the total interviewed. On the other hand, a similar group at private universities, 1329 of 3278 students used IEEE database, giving $40.54 \%$ of the total interviewed (see Table III). In Table III, the detail showed a great variance of the percentage of students that uses databases, i.e. between public and private universities non-significant difference were found for the use of databases in IEEE $(F=0.79, p=0.84)$, ScienceDirect $(\mathrm{F}=0.78, \mathrm{p}=1.16)$ and Hinari $(\mathrm{F}=0.44, \mathrm{p}=0.20)$.

TABLE II: COURSES RELATED TO COGNITIVE NEUROSCIENCE IN THE UNDERGRADUATE ICT PROGRAMS AT SOME UNIVERSITIES IN THE PERU

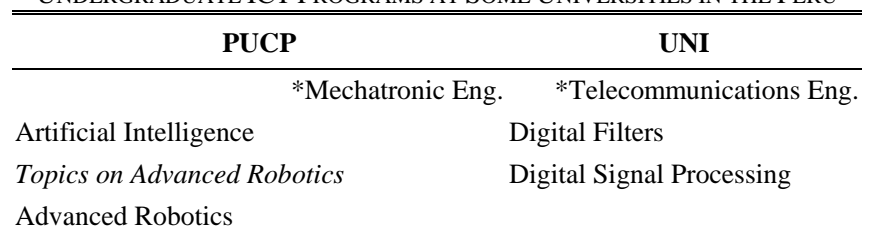

Computer Vision *Systems Eng.

*Electronics Eng. Artificial Intelligence

Elements of Biomedical Engineering Advanced Artificial

Informatics Engineering

Artificial Intelligence

Expert Systems

Human-Computer Interaction Intelligence

Data Mining
Robotics

Decision Processes

Mathematics | Statistics Decision Processes and Gaming Theory $\begin{array}{cc}\frac{\text { Uecision Processes and Gaming Theory }}{\text { UTP }} & \text { Intelligent Systems } \\ \text { *Mechatronic Eng. Neural Networks } & \end{array}$ *Systems Eng.

Digital Image Processing and Artificial Robotics Vision

Neural Networks and Fuzzy Logics

*Electronics Eng. *Industrial Eng.

Digital Image Processing and Artificial

Vision

Neural Networks and Fuzzy Logics

Biomedical Engineering

Digital Image Processing and Artificial

Vision

Neural Networks and Fuzzy Logics

Universidad Privada Telesup
*Electronics and Telecoms

Expert Systems

UNMSM

*Electronics Eng. *Electronics and Telecoms Eng. Robotics

Bioengineering

$*$ Systems and Telecom Eng.
Expert Systems

*Systems and Informatics Eng.

Artificial Intelligence

Expert Systems

Courses in italics have English teaching

* Each professional career is shown on the right.

TABLE III: PERUVIAN UNDERGRADUATE ELECTRONIC ENGINEERING

\begin{tabular}{lllllll}
\hline & \multicolumn{2}{c}{ IEEE } & \multicolumn{2}{c}{ Hinari } & \multicolumn{2}{c}{ Science Direct } \\
\hline University & Yes & \% & Yes & \% & Yes & \% \\
\hline UCSM & 188 & 60 & 12 & 4 & 41 & 13 \\
UPAO & 133 & 52 & 4 & 2 & 30 & 12 \\
PUCP & 233 & 34 & 46 & 7 & 97 & 14 \\
USMP & 104 & 49 & 4 & 2 & 12 & 6 \\
URP & 167 & 45 & 12 & 3 & 42 & 11 \\
UPC & 144 & 53 & 2 & 1 & 22 & 8 \\
ULA & 81 & 24 & 13 & 4 & 48 & 14
\end{tabular}




\begin{tabular}{lllllll} 
UTP & 152 & 26 & 16 & 3 & 76 & 13 \\
UCH & 22 & 15 & 7 & 5 & 28 & 19 \\
UANCV & 58 & 42 & 0 & 0 & 14 & 10 \\
UTA & 47 & 59 & 2 & 3 & 16 & 20 \\
\hline SubTotal & 1329 & 39.0 & 118 & 3.5 & 426 & 12.5 \\
\hline UNSA & 6 & 2 & 11 & 4 & 76 & 31 \\
UNAC & 330 & 50 & 13 & 2 & 80 & 12 \\
UNSAAC & 139 & 32 & 6 & 1 & 39 & 9 \\
UNH & 37 & 20 & 11 & 6 & 40 & 21 \\
UNSLG & 121 & 4 & 3 & 1 & 25 & 10 \\
UCP & 178 & 49 & 14 & 4 & 69 & 19 \\
UPRG & 120 & 34 & 3 & 1 & 31 & 9 \\
UNMSM & 271 & 51 & 5 & 1 & 52 & 10 \\
UNI & 190 & 45 & 10 & 2 & 52 & 12 \\
UNFV & 55 & 41 & 1 & 1 & 9 & 7 \\
UNSACA & 3 & 16 & 0 & 0 & 2 & 11 \\
UNTELS & 39 & 14 & 13 & 5 & 37 & 13 \\
UNP & 186 & 35 & 16 & 3 & 70 & 13 \\
UNA & 207 & 56 & 8 & 2 & 42 & 11 \\
\hline SubTotal & 1882 & 39.4 & 114 & 2.4 & 624 & 13.1 \\
\hline \hline
\end{tabular}

On the other hand, Computer Science and related careers with Computing Eng. and Informatics Eng. were considered: 43 programs were found in private universities and 22 in public universities. Results pointed to $22.4 \%$ for private universities and $19.4 \%$ for public universities. Again nonsignificant results of the $\mathrm{F}$ test of variance were found $(\mathrm{F}=1.42, \mathrm{p}=0.33)$. This non-significant result was explained considering that only two private $(70 \%$ and $54 \%)$ and one public $(47 \%)$ university were above the Electronic Eng. average (see Table IV).

TABLE IV: SAMPLE OF UNDERGRADUATE COMPUTER SCIENCE PROGRAMS AT PERUVIAN UNIVERSITIES - NAMES IN SPANISH

\begin{tabular}{lll}
\hline \hline \multicolumn{1}{c}{ PRIVATE UNIVERSITIES } & \multicolumn{1}{c}{ IEEE USE } & $\%$ \\
\hline UCSP-Ingeniería Informática & 184 & 70 \\
UCCI-Ingeniería Informática & 87 & 54 \\
UPAO-Ingeniería de Computación y & \multicolumn{2}{c}{ \% } \\
Sistemas & 198 & 38 \\
\hline Total of private universities & 2871 & 22.4 \\
\hline \multicolumn{1}{c}{ Public universities } & \multicolumn{1}{c}{ IEEE use } & $\%$ \\
\hline UNFV-Ingeniería Informática & 60 & 47 \\
\hline Total of public universities & 1015 & 19.4 \\
\hline \hline
\end{tabular}

\section{Aboriginal ICT Development in Cognitive Science}

Peru has a multiethnic population in the different microclimates due to Andean mountains and Amazonas River in a tropical zone. For example, there are studies of the methods of the social functions and medical treatment of "indigenous or traditional knowledge" which usually contrast with occidental "Knowledge" in urban or industrial society. These studies have revealed the knowledge of natural treatment by placing them in their social context from which is necessary to explain them and their positive effects [18]. This kind of reasoning added to parts B) and C) makes improvements in undergraduate students at promoting not only better knowledge for students but also a different economy supported by ICT. Examples of this development may be found at UNAP in the different games that illustrated some different animal characters in PlayStore such as Chinchilejo, Ontas and CharapitasFlyers by IquitosPlay [19], where US\$1 (S/.3) was paid to download the last game (see Fig. 1).

These aboriginal examples were done using different masks of existing applications, the interface human-machine allowed a better interaction and approach to Amazon people. Chinchilejo is a type of Dragonfly that remembers a legend about a man that liked bad news, a wizard changed him to a kind of Dragonfly to sparse good news (Fig. 1-A). On the other hand a Charapa is a Turtle, the game CharapitasFlyers is about to save Turtles making them fly (Fig. 1-C).

This finding was singular because the UNAP has Systems Eng. (but not Electronics Eng.) and reported only $12 \%$ of the use of the IEEE database.

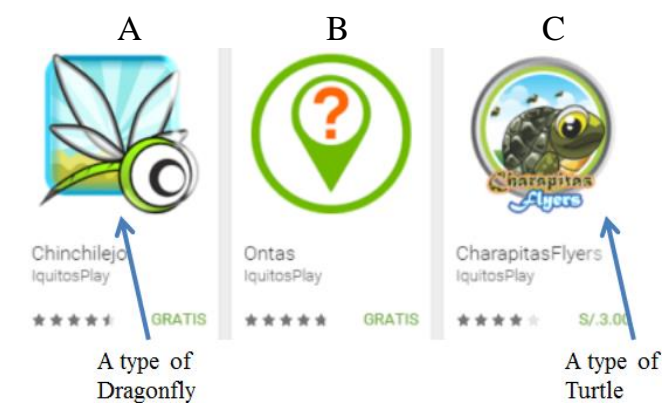

Fig. 1. Adaptation of screen captured to show Chinchilejo, Ontas and CharapitasFlyers games on PlayStore. Adapted from [19],

\section{E. Cognitive Neuroscience Course in Electrical Engineering Undergraduate Students}

Few ICT formative research groups were starting during the last few years in Peru. An initial group of 17 students started this course of Cognitive Neuroscience. The course was sponsored by the Electrical and Electronics Faculty of the UNI, flyer and contents were published [20]). The course finished with 7 students a long course of 13 sessions of 4 hours in 5 weeks plus three final meetings spaced by 2 weeks each (considering the time for learning consolidation). The total time rendered 68 hours between January and March in 2015 (see Fig. 2) during summer holidays.

Inspired in workshops of Neuroscience and ideas of cognitive computing [21] this course resulted in the preliminary approach 4 projects with students of Telecommunications and Electronic Engineering from 8th semester, interested in instrumentation and signal analysis performed in Cognitive Neurosciences. Through management of EEG free databases, these 4 groups considered the issues for the design of projects.

Therefore, monthly meetings at UCH reinforced the group of Cognitive Neuroscience at the UNI later. In April, two short papers have been arbitrated: Intercon in Huancayo and the Twentieth Symposium on Signal Processing, Images and Computer Vision, STSIVA -2015 in Colombia.

Nowadays two students have started a master's degree in Digital Signal Processing at UNI [22]. They got scholarships from by the Peruvian National Council for Science and Technology (CONCYTEC).

\section{F. Mixing Peer Review and Cognitive Neuroscience}

Considering the use of database (Table III) with courses 
related to cognitive neuroscience (Table II), there are three universities in the Scimago rankings, PUCP, UNMSM and UNI. PUCP had one course and IEEE database use with 34\%, less the average, while UNI and UNMSM had 2 courses each and were with $45 \%$ and $51 \%$, above the average. This suggested that although the lower university ranking, these courses may encourage students to use IEEE database. On the other hand, not clear differences were found for ScienceDirect database. This may change for the following census, because CONCYTEC is providing ScienceDirect to all universities since 2014 [23]. In addition, reconsidering curricula may help to Peru to improve in ITU (International Telecommunication Union) rankings that have decrease from 86th [24] to 105th [25] from 2010 to 2014.

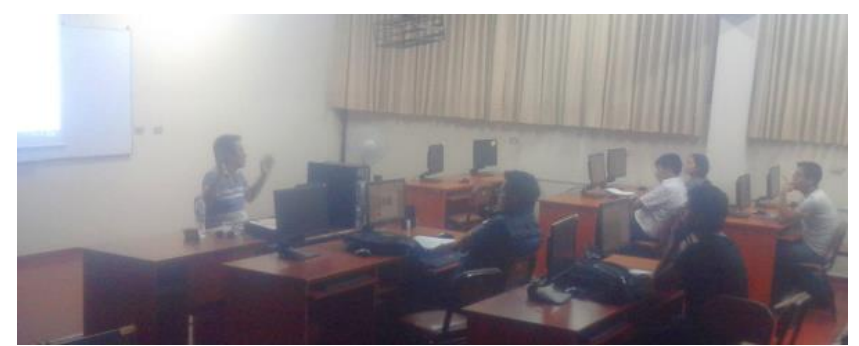

Fig. 2. A lecture of the cognitive neuroscience course in the summer of 2015 at UNI.

\section{DISCUSSION}

Overall, few aspects of Cognitive Neuroscience by undergraduate programs in Peruvian Universities were analyzed in Peru. Electronics Engineering Programs with similar average size of students were found in both private and public universities. Different number of public and private universities were found, but not significant difference between groups were found in science and engineering (IEEE) at around 39\%, medical (Hinari) at around 3\% and the highly diverse (ScienceDirect) at around 13\%. The difference was significant at the courses related to Cognitive neuroscience in a reduced set of universities, appearing more in Electronics Engineering.

Considering the results and different use of new subjects, such as suggested by formative research programs at $\mathrm{UCH}$ more work is need at several parts of coursework [15], it may work on other universities since the implementation of the current university law in Peru is changing Peruvian universities [13]. Therefore, an inventory of schools teaching cognitive neuroscience is very likely a useful thing for those teaching in the field in Peru. A further work to examine, for example, how cognitive neuroscience is applied in Peruvian context, or how each school teaches the material similarly or differently.

In Peru, many universities are highly criticized about their quality and one indicator is the small number of programs in science and engineering at different universities. This has conducted to implement careers without hardware teaching and producing the low rate of Electronics Engineering. In addition to that, different ways of Computer Science programs were implemented, a clear example is UCSP who rated $70 \%$ of student use of the IEEE database (being around $20 \%$ for most of the others). Therefore, Cognitive Neuroscience was found with some development in
Electronic Engineering and a future study may consider Cognitive neuroscience as a part of some course in the curricula in Computer Science. This may be related as a factor to the drop from 85 to 104 Peruvian positions in the ITU rankings [26].

Although the discussion may be highly criticized by these inferences, but Cognitive Neuroscience is a growing science that needs to be updated with last research. Therefore, the lack of database resources and low ICT markers (e.g. ITU ranking) would affect frontier fields such as Cognitive Neuroscience. Moreover, future education and jobs [27] will consider the Cognitive Neuroscience in ICT would create new education ways and non-routine cognitive jobs lying in Cognitive ICT technological developments.

Finally, science and engineering must support growth and development of South American countries. Current trends may be taken from the Journal of Neural Engineering that was created to help scientists, health workers and engineers to understand, replace, repair and improve the nervous system [28]. Therefore cognitive neuroscience in science and engineering can focus inside control and communication systems to codify a stream of signal that are not always easy to understand and/or to disentangle cognitive functions in inspired biosystems. Even more, traditional knowledge in Amazon towns can be preserved with a different approach that combines Psycholinguistic and Computer Science. On the other hand, one can consider consciousness as a physical object that in the cerebral cortex has a multidimensional representation of the world [29], which it seems most promising for exact sciences and engineering. The naturalistic and social points of view often seek applications, but the representations of consciousness are needed. In addition, neurodidactics seeks to improve learning through daily events, groups and affective [30]. Therefore further research with computer science, education and psycholinguistic can be opened for different small Peruvian cultures, such as the Amazon towns. Thus, Chinchilejo is a local legend that ICT help to be preserved; but other aspects of the legend may be worked, such as oral communication, legend influence in local culture and other groups with other legends along the different 42 small towns in the Amazon.

\section{ACKNOWLEDGMENT}

The present authors thanks for the course development to colleagues at UNI in the start of this work, Universidad de Lima, to continue this work and UNTELS to encourage finishing this work: L. Pizán-Toscano, R. Moreno-Martínez, D.E. Sal y Rosas-Celi, R. Infantes, views of $S$. Miñano-Suarez, and former views given by D. D. Potter.

\section{REFERENCES}

[1] M. E. Ruane. (2014). The Washington Post. [Online]. Available: http://www.washingtonpost.com/local/with-transplanted-arms-and-ar my-grit-a-quadruple-amputee-soldiers-on/2014/06/30/5130c242-f6e811e3-a3a5-42be35962a52_story.html

[2] C. A. Mugruza-Vassallo, "Modelagem matemática e simulação de potenciais de ação de unidades motoras (Master dissertation)," Universidade Sao Paulo, 2006.

[3] Nobel Prize. (2014). The Nobel Prize in physiology or medicine 2014 [Online]. Available: http://www.nobelprize.org/nobel_prizes/medicine/laureates/2014/ 
[4] E. C. Lagemann, An Elusive Science: The Troubling History of Education Research, Chicago and London: University of Chicago Press, 2000.

[5] C. Rama, "La nueva modalidad de educación virtual: la educación digital empaquetada de los MOOCs y las nuevas globouniversidades," La educación a distancia y virtual en Ecuador. Una nueva realidad universitaria, Loja: EDILOJA Cía. Ltda, 2013.

[6] QS TopUniversities. (2015). QS World University Rankings by Subject 2015 - Computer Science \& Information Systems. [Online]. Available: http://www.topuniversities.com/university-rankings/university-subject -rankings/2015/computer-science-information-systems\#sorting=rank+ region $=+$ country $=+$ facult $y=+$ stars $=$ false + search $=$

[7] MIT Webpage. (2015). Electrical engineering and computer science courses. [Online]. Available: http://ocw.mit.edu/courses/electrical-engineering-and-computer-scien ce/

[8] JupiterWeb. (2015). Ciência da Computação. Instituto de Matemática e Estatística. [Online]. Available: https://uspdigital.usp.br/jupiter-web/jupDisciplinaLista?codcg=45\&pf $\mathrm{xdisval}=\mathrm{MAC} \&$ tipo $=\mathrm{D}$

[9] JupiterWeb. (2015). Disciplina: IBM1098 - Introdução à Neurociência Computacional. Informática Biomédica. [Online]. Available: https://uspdigi-tal.usp.br/jupiterweb/obterDisciplina?sgldis=IBM1098 \&verdis $=1$

[10] JupiterWeb. (2015). Disciplina: IBM1068-Técnicas Quantit Aplicadas a Neuroimagem Estrutural.Informática Biomédica. [Online]. Available: https://uspdigital.usp.br/jupiterweb/obterDisciplina?sgldis=IBM1068 \&verdis $=2$

[11] T. Berger, "The four C's of neuroinformation theory: Coding, computing, control and cognition," IBM Research's 2006 Almaden Institute Conference on Cognitive Computing, 2006.

[12] INEI. (2014). Sistema de Consulta de Datos del II Censo Nacional Universitario 2010. Instituto Nacional de Estadística e Informática (INEI). [Online]. Available: http://censos.inei.gob.pe/cenaun/redatam_inei/\#

[13] Ley Universitaria, Ley $\mathrm{N}^{\mathrm{o}} 30220,2014$.

[14] Google Inc. (2014). Google Scholar. [Online]. Available: http://scholar.google.com/

[15] C. Mugruza-Vassallo, "Integral and transformative engineering coursework in formative research for undergraduate curricula,' presented at Frontiers in Education Conference (FIE), pp. 1-8, 2016.

[16] D. Baldwin, "Discovery learning in computer science," ACM SIGCSE Bulletin, vol. 28, pp. 222-226, 1996.

[17] B. Sabitzer and S. Pasterk, "Brain-based programming continued: Effective teaching in programming courses," in Proc. Frontiers in Education Conference (FIE), pp. 1-6, 2014.

[18] J. Gasché and J. A. Echevarri, "Diversidad social, conservación, transmisión cultural e innovación técnico-productiva en sociedades amazónicas. Sub-proyecto: Afirmación socio - cultural de la sociedad amazónica," Memoria Institucional del IIAP - 2012, p. 65, 2012.

[19] IquitosPlay. (2014). IquitosPlay games. [Online]. Available: https://play.google.com/store/apps/developer?id=IquitosPlay

[20] Universidad Nacional de Ingeniería. (2014). Curso taller "Instrumentación y Análisis en Neurociencia Cognitiva". [Online] Available: http://www.fiee.edu.pe/curso_taller2015

[21] D. S. Modha et al., "Cognitive computing," Communications of the $A C M$, vol. 54, no. 8, pp. 62-71, 2011.
[22] Universidad Nacional de Ingeniería. (2016). Becas Minedu Cienciactiva - Concytec. [Online]. Available: http://www.uni.edu.pe/index.php/eventos/item/1027-becas-minedu-ci enciactiva-concytec

[23] CONCYTEC. (2013). Consejo Nacional de Ciencia, Tecnología e Innovación Tecnológica. [Online]. Available: https://portal.concytec.gob.pe/index.php/informacion-cti/biblioteca-vi rtual

[24] International Telecommunication Union, "Measuring the information society: 2012," International Telecommunication Union, 2012.

[25] International Telecommunication Union, "Measuring the information society: 2014," International Telecommunication Union, 2014.

[26] C. A. Mugruza-Vassallo and S. Miñano-Suárez, "The role of information and communications technology, economy and patents in productivity of South-American Countries."

[27] M. Zappa, "Envisioning the future of education technology," Envisioningtech.com. United States Department of Labor: Futurework - Trends and Challenges for Work in the 21st Century, 2012.

[28] J. Engineering. (2014). Scope. Journal of Neural Engineering. [Online]. Available: http://iopscience.iop.org/1741-2552/page/Scope

[29] N. N. Pluzhnikova, "Naturalistic conceptions of consciousness in modern philosophy," World Applied Sciences Journal 30 (Management, Economics, Technology \& Tourism), pp. 141-143, 2014.

[30] S. M. U. Morales, “Algunas bases psicopedagógicas del aprendizaje y ciertos criterios para libros de texto de carácter crítico, reflexivo y descolonizador," Revista Integra Educativa, vol. 5, no. 1, pp. 155-169, 2012 .

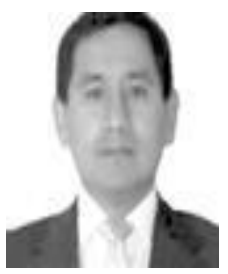

Carlos A. Mugruza-Vassallo was born in Huacho (Perú). He received a degree of doctor of philosophy degree from the University of Dundee, under SINAPSE sponsor, United Kingdom. He was awarded with a master degree in Electronic Systems from the University of Sao Paulo, Brazil. His major field is on electronics engineering from Pontificia Universidad Católica del Peru, Peru.

Carlos is principal professor at Universidad Tecnológica de Lima Sur, his main research interests include cognitive neuroscience and cognitive computing employing visual and auditory paradigms. On the other hand his research includes mechanical ventilation.

Prof. Mugruza is part of SINAPSE and University of Dundee as visiting scholar. He is part of the Cognitive Neuroscience Group since 2013.

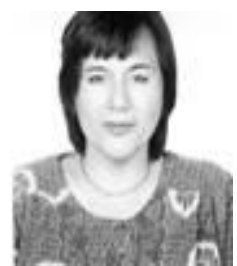

Yolanda C. Mugruza-Vassallo was born in Huacho (Perú). She received a degree of master degree on education from EUCIM: Escuela de Negocios y Administración de Empresas. Her major field is on biology from Universidad Nacional Mayor de San Marcos, Peru.

Yolanda is teacher at Asociación Educativa Trento, her main research interests include biology teaching, formative research and cognitive biology.

Mag. Mugruza is part of Cognitive Neuroscience Group that she helped to form with the initial proposal at 2013. 